\title{
Doença Hepática Poliquística Isolada
}

\author{
Isolated Polycystic Liver Disease
}

Rita Seara COSTA $\triangle^{1}$, Bruno GONÇALVES ${ }^{1}$, Ana Isabel REBELO ${ }^{1}$

Acta Med Port 2017 Nov;30(11):831-831 $\cdot$ https://doi.org/10.20344/amp.9326

Palavras-chave: Doenças do Fígado; Quistos

Keywords: Cysts; Liver Diseases
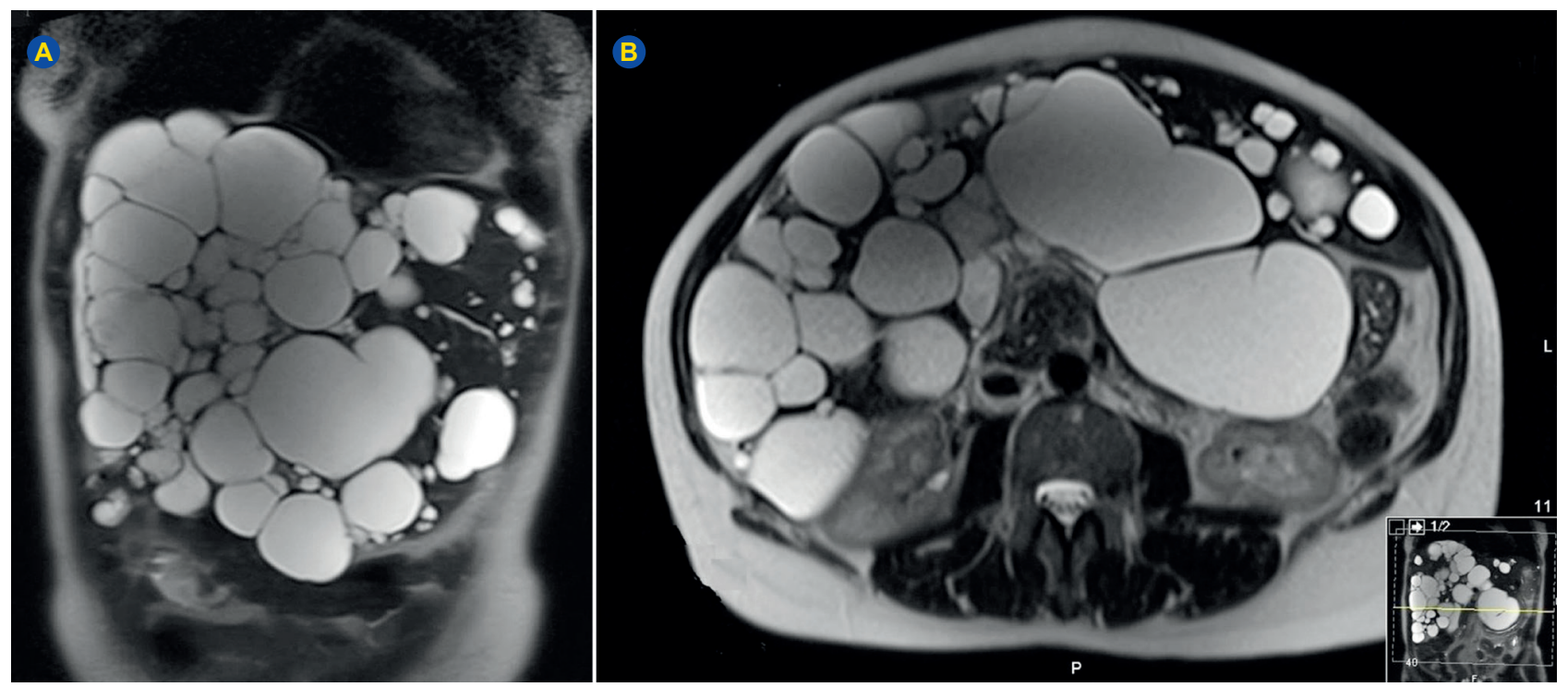

Figura 1 - Colangiografia por ressonância magnética (CRM), com ponderação em T2 (A) corte coronal: hepatomegalia com múltiplos quistos hepáticos simples de várias dimensões $(3 \mathrm{~mm}-98 \mathrm{~mm})$; (B) corte axial: múltiplos quistos hepáticos e apenas raros quistos corticais simples nos rins.

Doente de 56 anos, sexo feminino, com dispepsia e enfartamento pós-prandial cuja endoscopia digestiva alta mostrou compressão extrínseca e a ecografia abdominal quistos hepáticos. Estudo adicional com colangiografia por ressonância magnética (CRM) revelou múltiplos quistos hepáticos simples (mais de 20), sem envolvimento da via biliar intrahepática e raros quistos corticais renais (Fig.s 1A, 1B). $O$ estudo genético realizado identificou uma mutação heterozigótica no gene PRKCSH e confirmou o diagnóstico de doença hepática poliquística autossómica dominante..$^{1,2}$ Presentemente, a doente mantém enfartamento que meIhora com refeições fracionadas e toma de pró-cinéticos, os quistos hepáticos apresentam dimensões estáveis e, ela permanece em vigilância de possíveis complicações dos quistos e de hipertensão portal.
Esta entidade representa $7 \%$ dos casos de poliquistoses hepáticas cujo diagnóstico ocorre se mais de 20 quistos isolados no fígado na ausência de história familiar ou, um ou quatro quisto(s), se menos ou mais de 40 anos de idade, respetivamente, na presença de história familiar. ${ }^{2,3}$

\section{CONFIDENCIALIDADE DOS DADOS}

Os autores declaram ter seguido os protocolos do seu centro de trabalho acerca da publicação de dados. Foi devidamente obtido o consentimento informado do doente.

\section{CONFLITOS DE INTERESSE}

Os autores declaram não terem qualquer conflito de interesse relativamente ao presente artigo.

\section{REFERÊNCIAS}

1. Chandok N. Polycystic liver disease: a clinical review. Ann Hepatol. 2012;11:819-26.

2. Di Bisceglie AM, Befeler AS. Hepatic tumors and cysts. In: Feldman M, Friedman L, Brandt L, editors. Sleisenger and Fordtran's gastrointestinal and liver disease. $10^{\text {th }}$ ed. Philadelphia: Elsevier; 2016. p. 1623-5.

3. Cnossen WR, Drenth JP. Polycystic liver disease: an overview of pathogenesis, clinical manifestations and management. Orphanet J Rare Dis. $2014 ; 9: 69$.

\footnotetext{
1. Departamento de Gastrenterologia. Hospital de Braga. Braga. Portugal.

$\triangle$ Autor correspondente: Rita Seara Costa. rita.seara.costa@gmail.com

Recebido: 20 de junho de 2017 - Aceite: 14 de agosto de 2017 | Copyright $\odot$ Ordem dos Médicos 2017
} 